\title{
Atypical Presentation of Takotsubo Cardiomyopathy: Stroke as a Predisposing Factor
}

\section{Takotsubo Kardiyomiyopatisinin Atipik Sunumu: Predispozan Etken Olarak İnme}

\author{
Chan Wah LOONG $\odot$, Mohd Al-Baqlish Mohd FIRDAUS $\odot$, Mohd Ridzuan Mohd SAID $\odot$, Imran Zainal ABIDIN $\odot$
}

Ethics Committee Approval: Not Applicable.

Conflict of interest: The authors declare that they have no conflict of interest.

Funding: None.

Informed Consent: Informed consent was taken.
Cite as: Loong CW, Firdaus MABM, Said MRM, Abidin IZ. Atypical presentation of takotsubo cardiomyopathy: Stroke as a predisposing factor. Medeni Med J. 2020;35:26670 .

\begin{abstract}
Takotsubo syndrome is a rare disease and remained ambiguous with its etiology. The disease manifests in various clinical characteristics and even mimicking acute coronary syndrome. We are reporting a case of an elderly lady who manifested by unsteady gaits and recurrent falls. Subacute infarct of the right corona radiata was observed on the brain CT. In addition, coronary angiography and ventriculogram were performed because of dynamic ECG changes and elevated troponin I levels. The angiogram was normal while ventriculogram showed apical ballooning. She was diagnosed and treated as Takotsubo syndrome.
\end{abstract}

Keywords: Takotsubo cardiomyopathy, stroke, myocardial infarction, pericarditis

öz

Takotsubo sendromu nadir görülen bir hastalıktır ve etiyolojisi belirsizliğini sürdürmektedir. Hastalık çeşitli klinik özellikler sergilemekte ve hatta akut koroner sendromu taklit ederek kendini göstermektedir. Dengesiz yürüyüşler ve tekrarlayan düşmeler ile kendini gösteren yaşlı bir kadın olgusu bildirmekteyiz. Beyin BT'sinde sağ korona radiatasında subakut enfarktüsü gözlenmiştir. Illaveten, dinamik EKG değişiklikleri ve yüksek Troponin I seviyeleri nedeniyle koroner anjiyografi ve ventrikülogram yapılmıştır. Anjiyogram bulguları normalken, ventrikülogram apikal baloncuklar göstermiştir. Hastaya Takotsubo sendromu tanısı konularak tedavi edilmiştir.

Anahtar kelimeler: Takotsubo kardiyomiyopati, inme, miyokard enfarktüsü, perikardit
Received: 10 May 2020

Accepted: 19 July 2020

Online First: 30 September 2020

Corresponding Author:

M.A.B.M. Firdaus

ORCID: 0000-0002-9683-6683 University Malaya Medical Centre,

Department of Cardiology, Kuala Lumpur, Malaysia baqlish@gmail.com

C.W. Loong
ORCID: 0000-0001-8616-3975
I.Z. Abidin
ORCID: 0000-0002-3751-6946
University Malaya Medical
Centre, Department of Cardiology,
Kuala Lumpur, Malaysia
M.R.M. Said
ORCID: 0000-0001-8478-0849
International Islamic University,
Kulliyyah of Medicine, Department of
Internal Medicine,
Kuantan, Pahang, Malaysia




\section{INTRODUCTION}

Takotsubo syndrome (TTS) is named with multiple terms including Takotsubo cardiomyopathy (TCM), stress cardiomyopathy, ampulla cardiomyopathy, and broken heart disease. It is defined by reversible left ventricular apical ballooning in response to stressors ${ }^{1,2}$. "Tako-Tsubo" is derived from Japanese as "fishing pot for trapping octopus" and the disease is a great mimicker of acute myocardial infarction with ST-elevation on electrocardiogram (ECG) ${ }^{1,2}$. The actual pathophysiology of TTS remained uncertain, but few postulations were made including mainly its precipitation by by stressful triggers such as severe physical or emotional stressors ${ }^{1,2}$. As a great mimicker, our case with TTS presented with various clinical manifestations and thus we described an atypical presentation of TTS in an old lady who was manifested with a stroke.

\section{CASE REPORT}

A 77-year-old lady with no known medical illness was admitted to our hospital with recurrent episodes of falls within two days duration. She described the falls without any mechanical component, associated with dizziness and sustained causing several bruises over her face, right forearm, and bilateral legs. She also reported of unsteady gait which caused her to veer towards her right side. She denied any postural dizziness, weakness in the limbs, visual or speech disorder. She also had reduced exercise tolerance after multiple falls but denied any chest pain or palpitation.

On examination, she was oriented to time, place, and she had blood pressure of $135 / 70 \mathrm{mmHg}$ and the heart rate of $78 \mathrm{bpm}$. Her cardiovascular examination was unremarkable with no audible murmur or carotid bruit. Neurological examination revealed a reduced power for all limbs with the strength of 4 out of 5 . However, tones, reflexes, and sensations of extremity muscles were within normal limits. Examination of cranial nerves was unremarkable with negative cerebellar signs.

A baseline ECG (Figure 1) showed a sinus rhythm with concave ST segment elevation over leads I, II, V3 -V6 and reciprocal ST depression in lead III. Furthermore, PR elevation is observed in lead a VR. Hemoglobin value was $13.4 \mathrm{~g} / \mathrm{dL}$ with total white cell, and platelet counts of $16.4 \times 10^{9} / \mathrm{L}$ and $276 \times 10^{\circ} / \mathrm{L}$, respectively. Electrolytes were within normal ranges (urea, $6.4 \mathrm{mmol} / \mathrm{L}$; creatinine, 70 $\mathrm{mmol} / \mathrm{L}$, and potassium $3.7 \mathrm{mmol} / \mathrm{L}$ ). Troponin I was elevated $(14.51 \mathrm{ng} / \mathrm{mL})$.

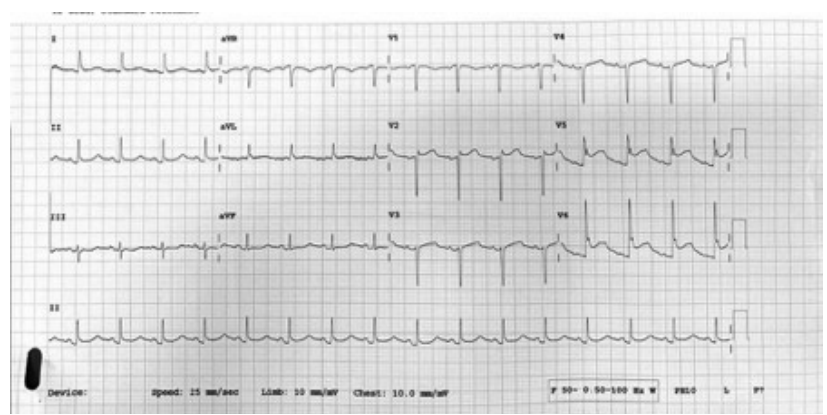

Figure 1. ECG shows concave ST elevation over lead I, II, V2, V5 and V6.

Computerized Tomography (CT) of the brain was performed (Figure 2) and reported as fairly ill-defined hypodensity at the right corona radiata in

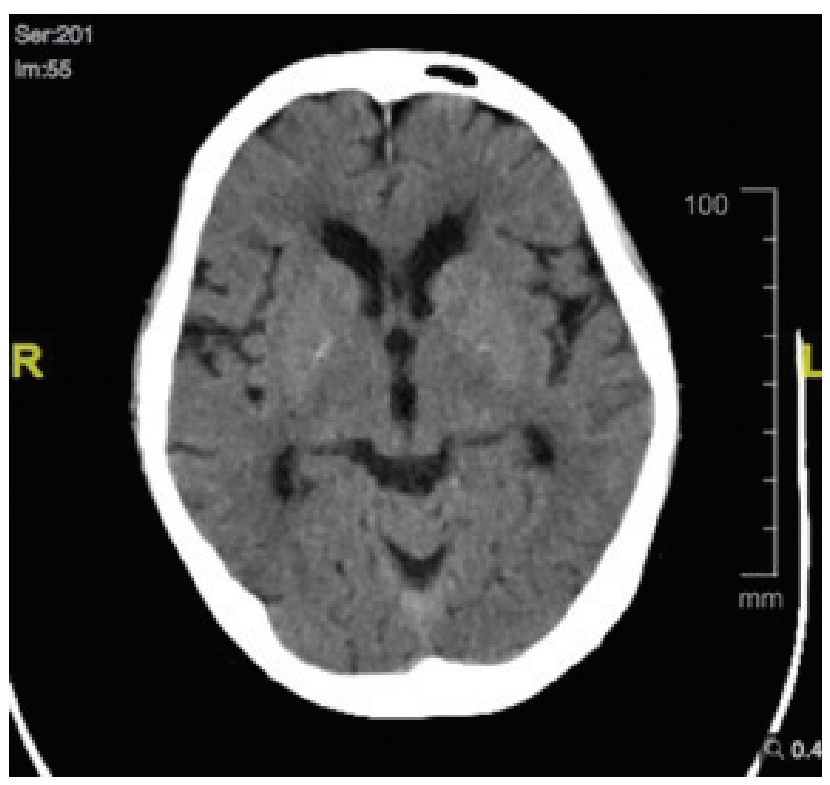

Figure 2. CT Brain shows subacute infarct of right corona radiata. 


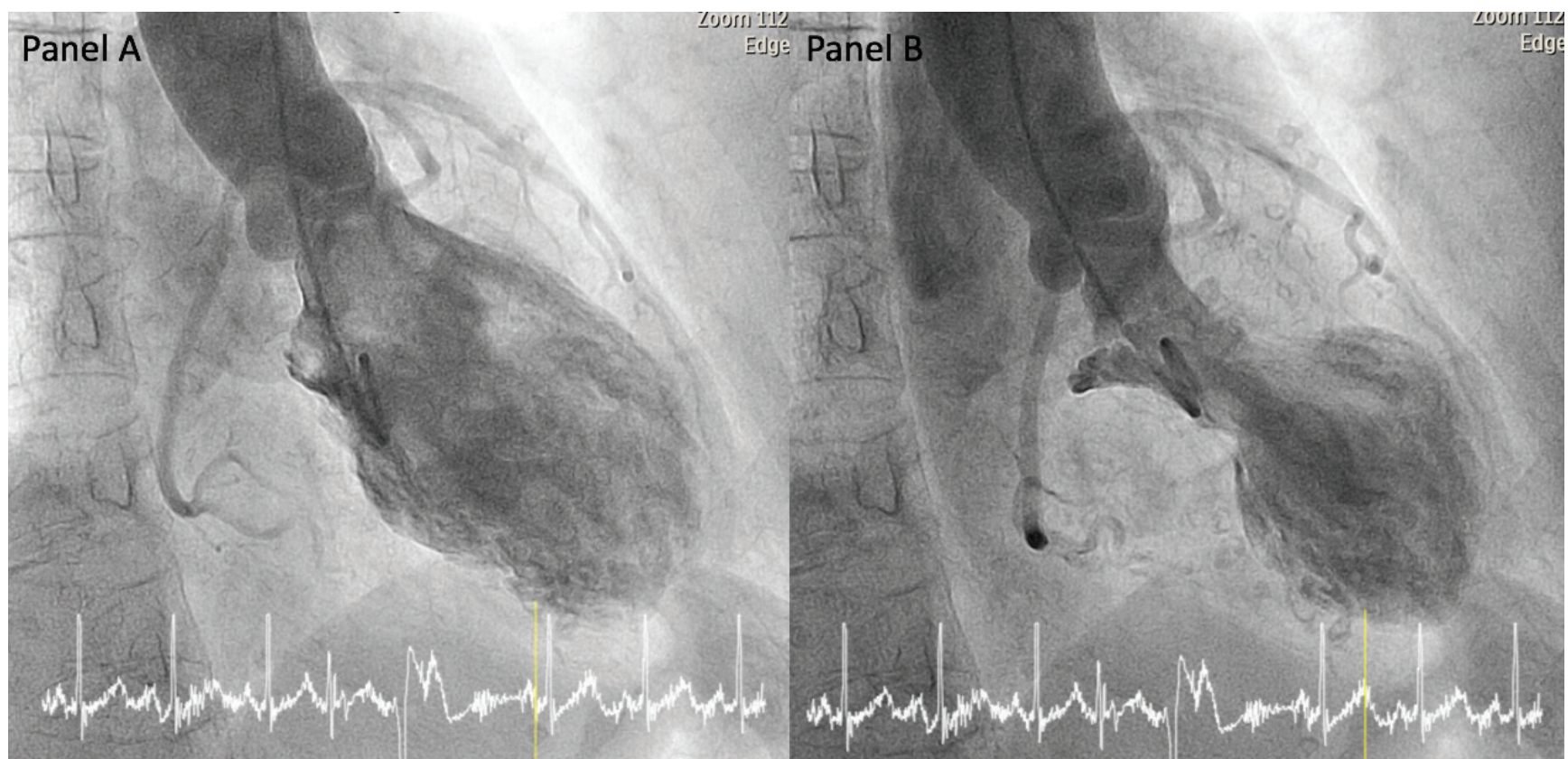

Figure 3. Penal A and B show the diastolic and systolic phase of ventriculogram which showing ventricular apical ballooning.

keeping with subacute infarcts, and well-defined hypodensities at the left head of caudate nucleus extending to the anterior horn of the left internal capsule, the left basal ganglia, and the left external capsule in keeping with chronic infarcts.

Thus, a diagnosis of lacunar infarct was made in correlation with her symptoms and CT brain findings. However, an additional diagnosis of acute coronary syndrome (ACS) was assumed in view of ECG changes with elevated troponin I level. Therefore, she was commenced on dual antiplatelet treatment and referred to a cardiologist. Emergency Coronary angiogram was arranged which revealed the presence of normal coronary arteries. Ventriculogram was performed, classical apical ballooning was shown, suggestive of Takotsubo Cardiomyopathy (Figure 3). Her recovery was uneventful, and she was discharged with daily doses of aspirin (100 mg), perindopril (2 $\mathrm{mg}$ ), atorvastatin (40 mg), and bisoprolol (1.25 $\mathrm{mg})$. She was subsequently seen in the outpatient clinic after a month with no neurological deficit. In addition, a transthoracic echocardiogram was performed on the same setting and noted ejec- tion fraction (EF) of $65 \%$ without regional wall motion abnormality.

\section{DISCUSSION}

Takotsubo Syndrome (TTS) was first reported by Sato et al. ${ }^{2}$ in 1990 via observation in 5 Japanese patients and since then, the entity has been recognized globally with a characteristic of transient regional systolic left ventricular dysfunction ${ }^{1}$. Previous literature described pathognomonic involvement of apical segment, but the variation of cardiac segments is demonstrated involving basal and even mid-ventricular regions. The pathogenesis of TTS remained uncertain, but few postulations were made focusing on the central and autonomic nervous system ${ }^{3}$. An increase of epinephrine and norepinephrine levels activated by the sympathetic nervous system was observed together with the surge of catecholamine which was consequently contributed to functional akinesia of left ventricular segments ${ }^{3}$.

Furthermore, a genetic predisposition such as $G$ protein-coupled receptor kinase 5 , estrogen re- 
ceptors, $\alpha 1$ and $\beta 1$-adrenergic receptor has been proposed but the susceptibility of these genes with familial TSS yielded conflicting evidence ${ }^{4}$. For instance, Mattsson et al. ${ }^{5}$ proved in their case-control trial that lack of association between ADRB1, GRK5 and BAG3 genes with familial TSS, and hence unlocked further potential genetic research.

The importance of stressors has been addressed by various literature sources, and notably emotional and physical factors are the commonest triggers $^{6-8}$. However, identifying the stressor was proven to be a challenging task as the trigger was established only in $85 \%$ of cases ${ }^{7}$. In a small proportion of cases with TSS, the trigger was unidentified and possible protective mechanism such as individual coping mechanisms and psychosocial factors may conceal the stressor ${ }^{8}$.

In terms of clinical features, chest pain $(75.9 \%)$ is the commonest symptom, followed by dyspnea $(46.9 \%)$, and syncope $(7.7 \%)^{9}$. Most of the patients complained of typically severe chest pain which which was exacerbated by exertion but in the absence of coronary plaque on angiogram ${ }^{7}$. Compared to ACS, TTS has been increasingly associated with a neurological or psychiatric disorder?. In addition, marked gender preference was described with more frequent occurrence among females which usually affected postmenopausal women between ages of 62 to 76 years ${ }^{10}$.

TTS was described in the setting of acute ischemic stroke and it was often asymptomatic ${ }^{11}$. Female gender and insular damage were the predominant features of the stroke patients who developed the cardiomyopathy ${ }^{11}$. Sardar MR et al. ${ }^{12}$ has reported a case of a 76-year-old Caucasian woman with no history of congestive heart failure who presented twice with Takotsubo cardiomyopathy with transient neurological complaints of aphasia. In our case, we believe that the stroke was the stressor that lead to Takotsubo cardiomyopathy.
The most recent validated criteria for TSS are the International Takotsubo Diagnostic Criteria (InterTAK Diagnostic Criteria) established by the European Society of Cardiology (ESC) ${ }^{13}$. The InterTAK Diagnostic Criteria take various variables including female sex; emotional and physical stress; no ST depression; psychiatric disorders; neurologic disorders; and QTc prolongation into the consideration $^{13}$. Based on the InterTAK Diagnostic Criteria, our patient has scored 71 , with the $88.7 \%$ probability of contracting TSS.

The mainstay management for TSS during the acute phase is mainly supportive treatment. In hemodynamically stable patients, angiotensin-converting enzyme (ACE) inhibitors and $\beta$-blockers are prescribed during the ventricular recovery period in order to improve ventricular contractility ${ }^{14}$. Moreover, additional therapeutic agents including antiplatelet therapy (aspirin alone or dual antiplatelet therapy) should be considered despite lacking consensus among experts ${ }^{15}$. In a study conducted by Dias $\mathrm{A}$ et al. $^{15}$ aspirin or dual antiplatelet therapy (aspirin + clopidogrel) were independent predictors for a lower incidence of Major Adverse Cardiovascular Events (MACE) during hospitalization for TTS. While our patient was treated with single antiplatelet (aspirin tablet $100 \mathrm{mg}$ daily), angiotensin-converting enzyme (ACE) inhibitors (perindopril tablet $2 \mathrm{mg}$ daily), and beta-blocker (bisoprolol tablet $1.25 \mathrm{mg}$ daily). TSS is a condition which was not fully understood and warranted for future research including exploration of gender predilection, triggering factors, the exact pathophysiologic mechanism, and its relationship with neurological disorder. Thus, this case illustrated the importance of clinical suspicion for TTS in a postmenopausal woman who had no typical symptoms of ACS but with neurological symptoms of ischemic stroke.

\section{CONCLUSION}

Takotsubo cardiomyopathy should be suspected in patients who had acute coronary syndrome 
with normal coronary artery. Acute neurological events could be stressors that lead to Takotsubo cardiomyopathy.

\section{REFERENCES}

1. Kurisu S, Sato H, Kawagoe T, et al. Tako-tsubo-like left ventricular dysfunction with ST-segment elevation: a novel cardiac syndrome mimicking acute myocardial infarction. Am Heart J. 2002;143:448-55. [CrossRef]

2. Hurst RT, Prasad A, Askew JW 3rd, Sengupta PP, Tajik AJ. Takotsubo cardiomyopathy: a unique cardiomyopathy with variable ventricular morphology. JACC Cardiovasc Imaging. 2010;3:641-9. [CrossRef]

3. Pelliccia F, Kaski JC, Crea F, Camici PG. Pathophysiology of Takotsubo Syndrome. Circulation. 2017;135:2426-41. [CrossRef]

4. Limongelli G, Masarone D, Maddaloni V, et al. Genetics of Takotsubo Syndrome. Heart Fail Clin. 2016;12:499506. [CrossRef]

5. Mattsson E, Saliba-Gustafsson P, Ehrenborg E, Tornvall P. Lack of genetic susceptibility in takotsubo cardiomyopathy: a case-control study. BMC Med Genet. 2018;19(1):39. Published 2018 Mar 7. [CrossRef]

6. Tsuchihashi K, Ueshima K, Uchida T, et al. Transient left ventricular apical ballooning without coronary artery stenosis: a novel heart syndrome mimicking acute myocardial infarction. Angina Pectoris-Myocardial Infarction Investigations in Japan. J Am Coll Cardiol. 2001;38:11-8. [CrossRef]
7. Sharkey SW, Lesser JR, Maron BJ. Cardiology Patient Page. Takotsubo (stress) cardiomyopathy. Circulation. 2011;124:e460-e2. [CrossRef]

8. Medina de Chazal H, Del Buono MG, Keyser-Marcus $\mathrm{L}$, et al. Stress Cardiomyopathy Diagnosis and Treatment: JACC State-of-the-Art Review. J Am Coll Cardiol. 2018;72:1955-71. [CrossRef]

9. Templin C, Ghadri JR, Diekmann J, et al. Clinical Features and Outcomes of Takotsubo (Stress) Cardiomyopathy. N Engl J Med. 2015;373:929-38. [CrossRef]

10. Schneider B, Sechtem U. Influence of Age and Gender in Takotsubo Syndrome. Heart Fail Clin. 2016;12:521-30. [CrossRef]

11. Yoshimura S, Toyoda K, Ohara T, et al. Takotsubo cardiomyopathy in acute ischemic stroke. Ann Neurol. 2008;64:547-54. [CrossRef]

12. Sardar MR, Kuntz C, Mazurek JA, Akhtar NH, Saeed W, Shapiro T. Recurrent takotsubo cardiomyopathy in the setting of transient neurological symptoms: a case report. J Med Case Rep. 2011;5:412. [CrossRef]

13. Ghadri JR, Wittstein IS, Prasad A, et al. International Expert Consensus Document on Takotsubo Syndrome (Part I): Clinical Characteristics, Diagnostic Criteria, and Pathophysiology. Eur Heart J. 2018;39:2032-46. [CrossRef]

14. Komamura K, Fukui M, Iwasaku T, Hirotani S, Masuyama T. Takotsubo cardiomyopathy: Pathophysiology, diagnosis and treatment. World J Cardiol. 2014;6:602-9. [CrossRef]

15. Dias A, Franco E, Koshkelashvili N, et al. Antiplatelet therapy in Takotsubo cardiomyopathy: does it improve cardiovascular outcomes during index event?. Heart Vessels. 2016;31:1285-90. [CrossRef] 